\title{
Potencial forrageiro e valor nutricional do feno de diferentes frações da parte aérea de quatro variedades de mandioca
}

\author{
Potential for forage and Nutritional value of hay of different fractions of the aerial \\ parts of four cassava varieties
}

\author{
SOUZA, André Santos de ${ }^{1}$; ROCHA JÚNIOR, Vicente Ribeiro ${ }^{2 *}$; MOTA, Álvaro \\ Diego Soares $^{3}$; ROCHA, Weder Jânsem Barbosa ${ }^{2}$; OLIVEIRA, Célio Roberto ${ }^{2}$; \\ AGUIAR, Ana Cássia Rodrigues de ${ }^{2}$; SANTOS, Carlos César Rodrigues dos ${ }^{2}$; \\ MENDES, Gustavo Almeida ${ }^{2}$
}

\author{
${ }^{1}$ Universidade Federal de Minas Gerais, Escola de Veterinária, Departamento de Zootecnia, Belo \\ Horizonte, Minas Gerais, Brasil. \\ ${ }^{2}$ Universidade Estadual de Montes Claros, Departamento de Ciências Agrárias, Janaúba, Minas Gerais, Brasil. \\ ${ }^{3}$ Instituto Federal do Norte de Minas, Salinas, Minas Gerais, Brasil. \\ *Endereço para correspondência: vicente.rocha@unimontes.br
}

\section{RESUMO}

Objetivou-se com este trabalho avaliar o potencial forrageiro e o valor nutricional do feno de diferentes frações da parte aérea de quatro variedades de mandioca. Utilizou-se um delineamento em blocos casualizados, esquema fatorial $4 \times 3$, com quatro repetições, composto de quatro variedades de mandioca (Amarelinha, Olho Roxo, Periquita e Sabará) e três formas de aproveitamento da parte aérea (Planta Inteira, Terço Superior e Sobras de Plantio). A variedade Periquita, quando considerada a fração planta inteira, apresentou maior potencial produtivo de feno e forragem. Os maiores valores de relação folha/haste foram encontrados na fração do terço superior. A variedade Amarelinha apresentou menor teor de lignina e fração $\mathrm{C}$ dos carboidratos e, juntamente, com a variedade Olho Roxo teve maior valor de nutrientes digestíveis totais. A fração do terço superior apresentou maior teor de proteína bruta e menores teores fibra e lignina, o que foi confirmado pelo fracionamento dos carboidratos. Quanto ao fracionamento proteico, não houve diferença entre as variedades de mandioca, todavia, a fração planta inteira teve menor valor na fração C. Para as frações proteicas B1 e B2 houve efeito de interação das variedades com as frações da parte aérea. A parte aérea das variedades de mandioca avaliadas nas diferentes frações apresenta bom potencial produtivo e os fenos produzidos da parte aérea e do terço superior das variedades Amarelinha e Olho Roxo apresentam melhor valor nutricional.

Palavras-chave: fracionamento de carboidratos, fracionamento de proteínas, nutrientes digestíveis totais.

\section{SUMMARY}

The objective to this was work evaluate the forage potential and nutritional value the hay, of different fractions of the aerial parts of four cassava varieties. We used a randomized complete block design, factorial design $4 \times 3$ with four replications being four varieties of cassava (Amarelinha, Olho Roxo, Periquita and Sabará) and three forms of exploitation of cassava foliage (Entire Plant, Superior Third, Surpluses of Planting). Variety Periquita used when the whole plant fraction showed better results on the productive potential of hay and forage. The highest values of leaf / foliage were found in the fraction of the upper third. The variety Amarelinha had lower lignin content and carbohydrate fraction $\mathrm{C}$ and together with the variety Olho Roxo had a higher value of TDN. The fraction of the upper third had the highest crude protein content and lower fiber and lignin, which was confirmed by fractionation of carbohydrates. As to the division protein did not differ between the cassava varieties, however, 
the fraction of the whole plant was lowest in fraction C. For protein fractions B1 and B2 was no interaction effect of varieties with the fractions of the shoot. We can conclude that the varieties of this study in the different fractions of the aerial have good productive potential and who also the hay produced the shoot and Olho Roxo Amarelinha varieties have better nutritional value, as well as the upper third of the hay.

Keywords: fractionation of carbohydrates, protein fractionation, total digestible nutrients.

\section{INTRODUÇÃO}

A baixa produção e a redução na qualidade da forragem, apresentadas pelas forrageiras tropicais, durante a época seca do ano, estão entre os fatores responsáveis pelos baixos índices de produtividade de leite e carne em todo o Brasil. Esse fato leva a necessidade de armazenamento de forragens de alto valor nutricional para alimentar os animais nessa época do ano. Nesse sentido, procuram-se espécies forrageiras que apresentem altas produções de matéria seca, com boa relação folha/colmo e alto valor nutricional (CARVALHO et al., 2006; MIRANDA et al., 2008). Além disso, a utilização de resíduos agroindustriais e outros ingredientes de potencial regional, utilizados de forma planejada, normalmente, no período crítico do ano, pode melhorar a eficiência dos sistemas de produção pecuária do semiárido (ARAÚJO et al., 2009; CARVALHO JÚNIOR. et al., 2009; PIRES et al., 2009; OLIVEIRA et al., 2009).

As pesquisas com mandioca (Manihot esculenta Crantz) e seus subprodutos (VONGSAMPHANH \& WANAPAT, 2004; CRUZ et al., 2006; FERREIRA et al., 2007) têm se destacado nos últimos anos, em decorrência da facilidade de cultivo, adaptabilidade a diversos tipos de solo, resistência a períodos de estiagem e expressiva produção, além da possibilidade de utilização da sua parte aérea (SCAPINELLO et al., 1999). Experiências anteriores têm demonstrado que a parte aérea da mandioca, conservada na forma de feno, é uma alternativa possível de ser incluída na formulação de rações para ruminantes (MODESTO et al., 2004). A composição nutricional e a produtividade do feno da parte aérea da cultura de mandioca dependem de algumas variáveis como variedade, idade da planta, espaçamento, adubação e condições edafoclimáticas (NUNES IRMÃO et al., 2008).

Assim, objetivou-se, nesta pesquisa, avaliar o potencial forrageiro e o valor nutricional dos fenos de diferentes frações da parte aérea de quatro variedades de mandioca cultivadas no Norte de Minas Gerais.

\section{MATERIAL E MÉTODOS}

O experimento foi conduzido na Fazenda Experimental da UNIMONTES, localizada no município de Janaúba, no Norte de Minas Gerais, no período de 17/12/2007 a 19/08/2008. A pluviosidade média anual da região é de aproximadamente $800 \mathrm{~mm}$ com temperatura média anual de $28^{\circ} \mathrm{C}$, umidade relativa do ar em torno de $65 \%$ e, segundo a classificação climática de Köppen, o tipo de clima predominante na região é o Aw.

Utilizou-se um delineamento em blocos casualizados, com esquema fatorial $4 \times 3$, com quatro repetições, composto de quatro variedades de mandioca utilizadas (Amarelinha, Olho Roxo, Periquita e Sabará) e três frações da parte aérea da mandioca (planta inteira, terço superior e sobras de plantio). A adoção do delineamento em blocos casualizados 
foi dada em função da possível interferência de algum fator não controlado na área experimental. As quatro variedades avaliadas estão entre as mais utilizadas pelos produtores da região, das quais três são de mesa (Amarelinha, Olho Roxo e Sabará) e uma brava (Periquita).

O plantio das variedades foi realizado nos dias 17 e 18/12/2007. Para tanto, utilizouse o espaçamento de um metro entre linhas e 0,75 metros entre plantas na linha, de forma a totalizar uma população final de 13.333 plantas por hectare. A parcela experimental foi constituída por seis linhas de plantio, com oito metros de comprimento cada, de maneira a compreender a área da parcela em $48 \mathrm{~m}^{2}$. Foi realizada a adubação de plantio com fontes de fósforo, potássio e adubação de cobertura com fonte de nitrogênio, aos 60 dias após a emergência das plântulas de mandioca, de acordo a recomendação de adubação para a cultura (GOMES et al., 1999), e observada a análise química do solo. As parcelas foram irrigadas, uma vez por semana, desde o plantio até a colheita, que aconteceu entre os dias 05/08/2008 e 19/08/2008.

Foi estabelecido como momento de colheita, aos oito meses de idade das plantas, aquele em que as raízes apresentavam aceitação por parte dos consumidores. Para a coleta dos dados, foram utilizadas as quatro linhas centrais de cada parcela e, nesse momento, foi executado o registro da produção forrageira por hectare e da relação folha/haste, das diferentes frações da parte aérea das quatro variedades de mandioca em cada uma das parcelas experimentais. A fração planta inteira foi determinada conforme o seguinte método: cortou-se a parte aérea total da planta a $20 \mathrm{~cm}$ do solo. A fração terço superior foi determinada como o terço superior da planta. A fração sobras do plantio foi constituída como a parte do caule da planta em que havia a presença de folhas e, após a retirada das manivas para o replantio da área, passou a ser considerada a fração remanescente.

Para a confecção do feno, as forragens colhidas foram, individualmente, picadas em tamanho médio, de partícula de $2 \mathrm{~cm}$, manualmente homogeneizadas e cerca de $3 \mathrm{~kg}$ das distintas frações das forragens de mandioca, produzidas em cada parcela, foram pesadas e submetidas ao processo de cura (secagem). Nesse processo, a forragem fresca foi distribuída em cima de lona plástica, em camada de $2-3 \mathrm{~cm}$ de espessura. Esse material foi mantido à sombra, periodicamente revirado, três vezes ao dia, de modo a lograr a homogeneização na desidratação, até atingir o ponto de feno do material picado (entre 10 e $15 \%$ de umidade). Em seguida, a forragem foi, novamente, pesada para se estimar o rendimento da produção de feno na matéria natural. Após tal processo, o material foi levado ao Laboratório de Análises de Alimentos da Universidade Estadual de Montes Claros para que fossem feitas as análises químicas do feno. No laboratório, inicialmente, procedeu-se a pré-secagem desse material em estufa de ventilação forçada a $55^{\circ} \mathrm{C}$ até atingir peso constante. Em seguida, a forragem pré-seca foi moída, em moinho tipo Willey, com peneira de $1 \mathrm{~mm}$. Do material moído, retirou-se amostras para que fossem avaliados quanto aos conteúdos de matéria seca (MS), matéria mineral $(\mathrm{MM})$, extrato etéreo (EE), segundo recomendações de Silva \& Queiroz (2006).

Os teores de fibra em detergente neutro (FDN), fibra em detergente ácido (FDA), celulose, hemicelulose e lignina foram determinados pelo método sequencial proposto por Van Soest et al. (1991). A proteína bruta $(\mathrm{PB})$ foi determinada pelo método de Kjedhal, o nitrogênio insolúvel em detergente neutro (NIDN) e o 
nitrogênio insolúvel em detergente ácido (NIDA) foram determinados a partir dos resíduos da FDN e FDA, respectivamente. A proteína insolúvel em detergente neutro (PIDN) e a proteína insolúvel em detergente ácido (PIDA) foram determinadas ao se multiplicar o valor do NIDN e NIDA por 6,25, segundo recomendações de Silva \& Queiroz (2006).

Os compostos nitrogenados, presentes nas amostras, foram subdivididos em: Fração A (nitrogênio não proteico ou NNP); Fração B1 (proteína solúvel de rápida degradação ruminal, peptídeios e oligopeptídeos); Fração B2 (proteína verdadeira ou citoplasmática de degradação ruminal intermediária); Fração B3 (proteína de lenta degradação ruminal, proteína associada a fibra em detergente neutro) e Fração $\mathrm{C}$ (proteína indigestível ou NIDA) - (FOX et al., 2002).

A porcentagem de carboidratos totais (CHT) foi obtida pela equação proposta por Sniffen et al. (1992), segundo a fórmula: $\mathrm{CHT}(\% \mathrm{MS})=100-[\mathrm{PB}$ $(\% \mathrm{MS})+\mathrm{EE}(\% \mathrm{MS})+\mathrm{CINZAS}$ (\%MS)]. Os carboidratos fibrosos (CF) foram obtidos a partir da fibra em detergente neutro corrigida para cinzas e proteína (FDNcp), enquanto que os carboidratos não fibrosos (CNF) foram calculados, segundo Hall (2003), pela diferença entre os CHT e a FDNcp de acordo com a fórmula: $\mathrm{CNF}(\% \mathrm{MS})=$ $\{100-[\mathrm{PB}(\% \mathrm{MS})+\mathrm{EE}(\% \mathrm{MS})+$ FDNcp (\%MS) + CINZAS (\%MS)] $\}$.

Para o fracionamento de carboidratos, a fração B2 (carboidratos estruturais, potencialmente digestíveis) foi obtida por diferença $(\mathrm{B} 2=$ FDNcp - Fração C), a fração $C$ (carboidrato indigestível no trato gastrintestinal dos ruminantes ou fração indigestível da fibra) foi estimada de acordo com Sniffen et al. (1992), em que C $(\% \mathrm{CHT})=[\mathrm{FDN}$ $(\% \mathrm{MS}) * 2,4 *$ lignina $(\% \mathrm{FDN}) / \mathrm{CHT}$
(\%MS)]. Cabe lembrar que a fração $\mathrm{A}+\mathrm{B} 1$ equivale aos carboidratos não fibrosos. $\mathrm{O}$ valor dos nutrientes digestíveis totais (NDT) foi estimado segundo NRC (2001).

$\mathrm{O}$ estudo da produção forrageira, produção de feno, percentual de rendimento de feno, relação folha/haste e valor nutricional do feno foi realizado segundo modelo estatístico:

$Y_{i j k}=\mu+B_{i}+V_{j}+F_{k}+V_{j k}+\varepsilon_{i j k}, e m$ que:

$\mathrm{Y}_{\mathrm{ijk}}=$ valor referente à observação do bloco i, da forma de aproveitamento da parte aérea $\mathrm{k}$, da variedade $\mathrm{j}$;

$\mu=$ média geral;

$\mathrm{B}_{\mathrm{i}}=$ efeito do bloco $\mathrm{i}(\mathrm{i}=1,2,3,4)$;

$\mathrm{V}_{\mathrm{j}}=$ efeito da variedade $\mathrm{j}(\mathrm{i}=1,2,3,4)$;

$\mathrm{F}_{\mathrm{k}}=$ efeito da forma de aproveitamento da parte aérea $\mathrm{k}(\mathrm{k}=1,2,3)$;

$\mathrm{VF}_{\mathrm{jk}}=$ efeito da interação variedade $\mathrm{j} x$ forma de aproveitamento da parte aérea $\mathrm{k}$;

$\varepsilon_{\mathrm{ijk}}=$ erro experimental aleatório associado à todas as observações, que por hipótese tem distribuição normal, média zero e variância $\sigma^{2}$.

Os dados obtidos foram submetidos à análise de variância, através do programa SISVAR (Ferreira, 2000), e ainda, para efeito de comparação de médias, utilizou-se o Teste de Scott \& Knott ao nível de 5\% de significância.

\section{RESULTADOS E DISCUSSÃO}

Não houve efeito $(\mathrm{P}>0,05)$ de interação da variedade com a fração da parte aérea para as variáveis estudadas (Tabela 1). Ao se analisar as diferentes variedades em relação à produção de forragem e produção de feno na matéria natural e na matéria seca, em toneladas por hectare $(\mathrm{t} / \mathrm{ha})$, observou-se que a variedade Periquita apresentou maior produtividade (Tabela 1). No entanto, as 
variedades Amarelinha e Olho Roxo apresentaram valores mais elevados para percentual de rendimento de feno (\%). Já para a relação folha/haste não foi encontrada diferença significativa $(\mathrm{P}>0,05)$.

Azevedo et al. (2006), ao avaliarem três variedades de mandioca, duas classificadas como de mesa (S 60-10 e Frita) e uma outra forrageira (Fepagro RS-13), no município de Vera Cruz-RS, encontraram valores para produção de matéria seca de 3,24; 5,87 e 4,09t/ha, para as respectivas variedades. Em relação à produção de feno, Souza et al. (2001), encontraram produtividades médias de 5,8; 5,2 e 5,0t/ha de matéria natural para a variedade Platinão, submetida a plantio com diferentes espaçamentos. Já em relação ao percentual de rendimento de feno, Nunes Irmão et al. (2008) encontraram valores de $22,35,22,90$ e $22,23 \%$, no estudo da variedade Coqueiro aos 8; 10 e 12 meses de idade, respectivamente.

Tabela 1.Produção de forragem do material original na matéria natural e matéria seca, produção de feno na matéria natural e matéria seca, em toneladas por hectare (t/ha), percentual de rendimento de feno (\%) e relação folha/haste de quatro variedades de mandioca cultivadas no Norte de Minas Gerais

\begin{tabular}{lcccccc}
\hline Variedade & $\begin{array}{c}\text { Produção } \\
\text { Forragem } \\
(\mathrm{MN})\end{array}$ & $\begin{array}{c}\text { Produção } \\
\text { Forragem } \\
(\mathrm{MS})\end{array}$ & $\begin{array}{c}\text { Produção } \\
\text { Feno } \\
(\mathrm{MN})\end{array}$ & $\begin{array}{c}\text { Produção } \\
\text { Feno } \\
(\mathrm{MS})\end{array}$ & $\begin{array}{c}\text { Rendimento } \\
\text { Feno }(\%)\end{array}$ & $\begin{array}{c}\text { Relação } \\
\text { Folha/Haste }\end{array}$ \\
\hline Amarelinha & $11,64^{\mathrm{b}}$ & $2,89^{\mathrm{b}}$ & $3,13^{\mathrm{b}}$ & $2,87^{\mathrm{b}}$ & $26,75^{\mathrm{a}}$ & $0,52^{\mathrm{a}}$ \\
Olho Roxo & $11,83^{\mathrm{b}}$ & $3,01^{\mathrm{b}}$ & $3,22^{\mathrm{b}}$ & $2,98^{\mathrm{b}}$ & $27,50^{\mathrm{a}}$ & $0,53^{\mathrm{a}}$ \\
Periquita & $23,52^{\mathrm{a}}$ & $4,91^{\mathrm{a}}$ & $5,41^{\mathrm{a}}$ & $4,12^{\mathrm{a}}$ & $22,76^{\mathrm{c}}$ & $0,55^{\mathrm{a}}$ \\
Sabará & $12,54^{\mathrm{b}}$ & $2,94^{\mathrm{b}}$ & $3,16^{\mathrm{b}}$ & $2,89^{\mathrm{b}}$ & $24,84^{\mathrm{b}}$ & $0,44^{\mathrm{a}}$ \\
\hline Média Geral & 14,89 & 3,43 & 3,73 & 3,21 & 25,46 & 0,51 \\
\hline CV $(\%)$ & 30,78 & 29,53 & 34,20 & 27,79 & 6,37 & 27,52 \\
\hline
\end{tabular}

$\mathrm{MN}=$ matéria natural; $\mathrm{MS}=$ matéria seca.

Médias seguidas de mesma letra, na coluna, não diferem estatisticamente entre si pelo teste Scott \&

Knott ao nível de $5 \%$ de significância.

Os dados encontrados pelos autores supracitados mostram que as variedades estudadas neste experimento possuem bom potencial para produção de feno. Ressalta-se que tais variedades foram colhidas aos oito meses de idade, ou seja, as plantas ainda estavam jovens.

Embora as variedades Amarelinha e Olho Roxo tenham apresentado melhores percentuais de rendimento de feno, a produção de forragem e de feno foram inferiores em relação à Periquita. Tal fato pode ser explicado devido a essas variedades apresentarem altura de planta inferior (1,92 e 1,99m para Amarelinha e Olho Roxo, respectivamente, contra, 2,21 e 2,28m, para Periquita e Sabará, respectivamente). Números compreensíveis quando se considera a natureza da variedade, que concentra em sua estrutura uma menor relação água/sólidos, o que faz com que, ao sofrerem o processo de fenação, obtenham um maior percentual de rendimento de sólidos. Os teores de matéria seca da forragem fresca variaram de 20,90 a $25,22 \%$. Da mesma forma, embora o percentual de rendimento e a 
produção de forragem e feno sejam diferentes, nas variedades analisadas a relação folha/haste pôde não variar em função de algumas características específicas da própria cultura, como: estrutura da folha, tamanho da folha, espessura do caule, etc.

Ao se analisar as diferentes frações da parte aérea, foi notada diferença estatística $(\mathrm{P}<0,05)$ em relação a produção de forragem, produção de feno na matéria natural e na matéria seca em toneladas por hectare (t/ha). Destaca-se que a fração planta inteira apresentou maior produtividade seguidas das frações sobras de plantio e terço superior. Quanto à relação folha/haste $(\mathrm{P}<0,05)$, a fração terço superior apresentou melhores resultados, seguido da fração sobras de plantio e planta inteira, respectivamente (Tabela 2). Já para o percentual de rendimento de feno, não foi observada diferença estatística $(\mathrm{P}>0,05)$.

Tabela 2. Produção de forragem do material original na matéria natural e matéria seca, produção de feno na matéria natural e matéria seca, em toneladas por hectare (t/ha), percentual de rendimento de feno (\%) e relação folha/haste de diferentes frações da parte aérea de variedades de mandioca

\begin{tabular}{lcccccc}
\hline $\begin{array}{l}\text { Fração da } \\
\text { parte aérea }\end{array}$ & $\begin{array}{c}\text { Produção } \\
\text { Forragem } \\
(\mathrm{MN})\end{array}$ & $\begin{array}{c}\text { Produção } \\
\text { Forragem } \\
(\mathrm{MS})\end{array}$ & $\begin{array}{c}\text { Produção } \\
\text { Feno (MN) }\end{array}$ & $\begin{array}{c}\text { Produção } \\
\text { Feno (MS) }\end{array}$ & $\begin{array}{c}\text { Rendimento } \\
\text { Feno (\%) }\end{array}$ & $\begin{array}{c}\text { Relação } \\
\text { Folha/Haste }\end{array}$ \\
\hline $\begin{array}{l}\text { Planta Inteira } \\
\text { Terço }\end{array}$ & $21,82^{\mathrm{a}}$ & $5,16^{\mathrm{a}}$ & $5,57^{\mathrm{a}}$ & $4,47^{\mathrm{a}}$ & $25,96^{\mathrm{a}}$ & $0,30^{\mathrm{c}}$ \\
$\begin{array}{l}\text { Superior } \\
\begin{array}{l}\text { Sobras de } \\
\text { Plantio }\end{array}\end{array}$ & $9,41^{\mathrm{c}}$ & $2,23^{\mathrm{c}}$ & $2,31^{\mathrm{c}}$ & $2,13^{\mathrm{c}}$ & $25,09^{\mathrm{a}}$ & $0,68^{\mathrm{a}}$ \\
\hline Média Geral & $13,42^{\mathrm{b}}$ & $3,17^{\mathrm{b}}$ & $3,31^{\mathrm{b}}$ & $3,05^{\mathrm{b}}$ & $25,34^{\mathrm{a}}$ & $0,54^{\mathrm{b}}$ \\
\hline CV $(\%)$ & 14,89 & 3,52 & 3,73 & 3,21 & 25,46 & 0,51 \\
\hline
\end{tabular}

$\mathrm{MN}$ = matéria natural; $\mathrm{MS}$ = matéria seca.

Médias seguidas de mesma letra, na coluna, não diferem estatisticamente entre si pelo teste Scott \& Knott ao nível de 5\% de significância.

Moura \& Costa (2001), no município de Rio Grande no Acre, em pesquisa da produtividade da parte aérea de cinco variedades de mandioca (Paxiubão, Paxiúba II, Metro II, Pretinha e Pirarucu), aos 6 meses de idade em dois sistemas de poda $(0,50 \mathrm{~m}$ e $1,00 \mathrm{~m})$, encontraram valores médios de produção de massa seca que oscilavam de 6 a 9 e 4 a 8t/ha, respectivamente. No que respeita à produção de feno, Nunes Irmão et al. (2008) avaliaram a porção terço superior e encontraram os valores de 1,04 a $2,91 \mathrm{t} / \mathrm{ha}$ de matéria verde e 0,93 a $2,47 \mathrm{t} /$ ha de matéria seca em plantas com idade de 8 a 18 meses, respectivamente.
Ao pesquisarem o rendimento de feno, Nunes Irmão et al. (2008) observaram médias de 22,20, 18,18 e 26,39\% no feno do terço superior da variedade Coqueiro colhida aos 14, 16 e 18 meses, respectivamente.

Neste experimento, pôde-se observar que, embora as porções utilizadas fossem diferentes, a concentração de água na planta encontrou-se bem distribuída na parte aérea em plantas mais jovens. Conforme já descrito, a o terço superior apresentou melhor relação folha/haste em relação às demais frações da parte aérea. Quanto ao valor nutricional do feno, houve efeito de interação $(\mathrm{P}<0,05)$ de 
variedade e fração da parte aérea, apenas, para as frações nitrogenadas B1 e B2. Ao comparar as variedades (Tabela 3) quanto aos teores de matéria seca, proteína bruta, matéria mineral, fibra em detergente neutro, fibra em detergente ácido, celulose, hemicelulose e extrato etéreo, não foi encontrada diferença significativa $(\mathrm{P}>0,05)$. No entanto, para os teores de nutrientes digestíveis totais, observou-se que as variedades Amarelinha e Olho
Roxo apresentaram médias superiores às variedades Periquita e Sabará e, ao se avaliar os teores de lignina, a variedade Amarelinha apresentou os menores teores $\quad(\mathrm{P}<0,05)$. Possivelmente, $\mathrm{O}$ menor diâmetro da rama, encontrado nas variedades Amarelinha e Olho Roxo, está relacionado aos melhores resultados do feno quanto aos teores de lignina $\mathrm{e}$ nutrientes digestíveis totais.

Tabela 3. Teores de matéria seca (MS) e composição química, em percentagem da matéria seca, do feno de quatro variedades de mandioca

\begin{tabular}{lcccccccccc}
\hline Variedade & MS & PB & MM & FDN & FDA & CEL & HEM & LIG & EE & NDT \\
\hline Amarelinha & $91,54^{\mathrm{a}}$ & $17,11^{\mathrm{a}}$ & $7,77^{\mathrm{a}}$ & $76,7^{\mathrm{a}}$ & $50,97^{\mathrm{a}}$ & $21,80^{\mathrm{a}}$ & $25,77^{\mathrm{a}}$ & $16,78^{\mathrm{a}}$ & $7,44^{\mathrm{a}}$ & $58,84^{\mathrm{a}}$ \\
Olho Roxo & $92,41^{\mathrm{a}}$ & $16,67^{\mathrm{a}}$ & $7,54^{\mathrm{a}}$ & $76,2^{\mathrm{a}}$ & $48,02^{\mathrm{a}}$ & $22,18^{\mathrm{a}}$ & $28,27^{\mathrm{a}}$ & $19,18^{\mathrm{b}}$ & $8,12^{\mathrm{a}}$ & $56,69^{\mathrm{a}}$ \\
Periquita & $91,53^{\mathrm{a}}$ & $18,20^{\mathrm{a}}$ & $8,05^{\mathrm{a}}$ & $77,2^{\mathrm{a}}$ & $52,65^{\mathrm{a}}$ & $22,44^{\mathrm{a}}$ & $24,63^{\mathrm{a}}$ & $18,70^{\mathrm{b}}$ & $8,32^{\mathrm{a}}$ & $52,99^{\mathrm{b}}$ \\
Sabará & $91,91^{\mathrm{a}}$ & $18,41^{\mathrm{a}}$ & $7,59^{\mathrm{a}}$ & $78,2^{\mathrm{a}}$ & $50,35^{\mathrm{a}}$ & $19,19^{\mathrm{a}}$ & $27,86^{\mathrm{a}}$ & $18,87^{\mathrm{b}}$ & $6,71^{\mathrm{a}}$ & $49,55^{\mathrm{b}}$ \\
\hline Média Geral & 91,85 & 17,60 & 7,74 & 77,14 & 50,50 & 21,40 & 26,63 & 18,38 & 7,65 & 54,52 \\
\hline CV (\%) & 1,71 & 13,29 & 8,61 & 4,28 & 10,73 & 30,47 & 15,90 & 10,21 & 19,60 & 7,71 \\
\hline
\end{tabular}

MS = matéria seca; $\mathrm{PB}=$ proteína bruta; $\mathrm{MM}=$ matéria mineral; $\mathrm{FDN}$ = fibra em detergente neutro; $\mathrm{FDA}=$ fibra em detergente ácido; $\mathrm{CEL}=$ celulose; $\mathrm{HEM}=$ hemicelulose $; \mathrm{LIG}=$ lignina; $\mathrm{EE}=$ extrato etéreo; NDT = nutrientes digestíveis totais.

Médias seguidas de mesma letra, na coluna, não diferem estatisticamente entre si pelo teste Scott \& Knott ao nível de 5\% de significância.

Nunes Irmão et al. (2008), no estudo do feno da variedade de mandioca Coqueiro, no Sudoeste Baiano, encontraram, em plantas colhidas aos 8 e 14 meses de plantio, valores médios de 90,$14 ; 22,84$; 9,$13 ; 2,76 ; 54,11 \%$ e 87,$23 ; 19,07 ; 9,13$; 2,08 e $42,72 \%$ para MS, PB, MM, EE e NDT, respectivamente. Tais autores avaliaram ainda o mesmo corpus aos $10 \mathrm{e}$ 16 meses de idades de corte e observaram os teores de 50,69 e 54,18\%; 33,73 e $38,35 \% ; 16,96$ e $15,83 \% ; 23,63$ e $24,26 \% ; 10,10$ e $14,09 \%$ para FDN, FDA, hemicelulose, celulose e lignina, respectivamente.

Se comparados os resultados desta pesquisa com os dados encontrados por Nunes Irmão et al. (2008), é possível apontar que os valores de MS e EE foram superiores, enquanto que, os valores de PB e MM foram inferiores, embora $\mathrm{o}$ resultado de NDT da variedade Coqueiro, aos 8 meses, se encontre no intervalo de valores apontados para as variedades Amarelinha, Olho Roxo, Periquita e Sabará. Dessa forma, fica evidente como as diferenças edafoclimáticas e varietais podem intervir no valor nutricional da forragem.

No que concerne aos teores de matéria seca, celulose, hemicelulose e nutrientes digestíveis totais (Tabela 4), observa-se que não houve diferença $(\mathrm{P}>0,05)$ entre as frações da parte aérea. No entanto, houve diferença significativa $(\mathrm{P}<0,05)$ para os teores de proteína bruta e matéria mineral, 
visto a fração do terço superior ter apresentado os maiores teores. Para a fibra em detergente ácido e a lignina, o terço superior apresentou os menores teores. O feno da planta inteira teve menor porcentagem de extrato etéreo e maior teor de FDN. A melhor relação folha : haste, no terço superior, contribuiu para melhor composição nutricional do feno produzido a partir dessa fração. Já o alto teor de FDN no feno da planta inteira se deve à menor relação folha : haste nessa fração da planta (Tabela 2).

Tabela 4. Teores de matéria seca (MS) e composição química, em percentagem da matéria seca, do feno de diferentes frações da parte aérea da mandioca

\begin{tabular}{lcccccccccc}
\hline $\begin{array}{l}\text { Fração da parte } \\
\text { aérea }\end{array}$ & MS & PB & MM & FDN & FDA & CEL & HEM & LIG & EE & NDT \\
\hline Planta inteira & $91,27^{\mathrm{a}}$ & $14,49^{\mathrm{c}}$ & $6,65^{\mathrm{c}}$ & $81,12^{\mathrm{a}}$ & $54,69^{\mathrm{a}}$ & $20,29^{\mathrm{a}}$ & $26,42^{\mathrm{a}}$ & $19,31^{\mathrm{a}}$ & $6,32^{\mathrm{b}}$ & $53,43^{\mathrm{a}}$ \\
Terço superior & $92,21^{\mathrm{a}}$ & $20,65^{\mathrm{a}}$ & $8,57^{\mathrm{a}}$ & $72,43^{\mathrm{c}}$ & $43,91^{\mathrm{b}}$ & $21,78^{\mathrm{a}}$ & $28,52^{\mathrm{a}}$ & $16,96^{\mathrm{b}}$ & $8,67^{\mathrm{a}}$ & $56,06^{\mathrm{a}}$ \\
Sobras de plantio & $92,07^{\mathrm{a}}$ & $17,65^{\mathrm{b}}$ & $7,99^{\mathrm{b}}$ & $77,86^{\mathrm{b}}$ & $52,89^{\mathrm{a}}$ & $22,14^{\mathrm{a}}$ & $24,96^{\mathrm{a}}$ & $18,88^{\mathrm{a}}$ & $7,95^{\mathrm{a}}$ & $54,05^{\mathrm{a}}$ \\
\hline Média geral & 91,85 & 17,60 & 7,74 & 77,14 & 50,50 & 21,40 & 26,63 & 18,38 & 7,65 & 54,52 \\
\hline CV $(\%)$ & 1,71 & 13,29 & 8,61 & 4,28 & 10,73 & 30,47 & 15,90 & 10,21 & 19,60 & 7,71 \\
\hline
\end{tabular}

MS = matéria seca; $\mathrm{PB}=$ proteína bruta; $\mathrm{MM}=$ matéria mineral; FDN = fibra em detergente neutro; $\mathrm{FDA}=$ fibra em detergente ácido; $\mathrm{CEL}=$ celulose; $\mathrm{HEM}=$ hemicelulose $; \mathrm{LIG}=$ lignina; $\mathrm{EE}=$ extrato etéreo; NDT = nutrientes digestíveis totais.

Médias seguidas de mesma letra, na coluna, não diferem estatisticamente entre si pelo teste Scott \& Knott ao nível de 5\% de significância.

Os resultados deste experimento encontram-se no intervalo de médias apontadas por Figueiredo et al. (2006) $(20,88 \%$ de PB, $58,06 \%$ de FDN e $38,6 \%$ de FDA, para o feno do terço superior da parte aérea de mandioca) e Pinho et al. (2004) $(54,4 \%$ de FDN, $11,76 \%$ de lignina e 47,54\% de FDA, para o feno da parte aérea total da mandioca), de modo a confirmar o bom valor nutricional das três frações da parte aérea da mandioca, especialmente, em relação aos teores de PB. Os melhores resultados encontrados para a fração terço superior para essas variáveis se explica pela maior proporção de folhas, que implica numa qualidade nutricional superior às demais frações da planta. Da mesma forma, os altos valores de FDN, encontrados na fração planta inteira, estão relacionados à alta proporção de caule, encontrada nesta, o que contribui para o seu alto teor de fibra em relação às outras frações analisadas. Por outro lado, não foram detectados altos valores quando analisado o teor de $\mathrm{EE}$ dessa fração, pois grande parte do EE encontra-se nas folhas e, justamente, nessa fração ocorre menor proporção de folhas, se comparada com a fração terço superior e sobras de plantio.

Em relação ao fracionamento proteico (fração A, B3 e C) e quanto aos níveis de nitrogênio insolúvel em detergente neutro, proteína insolúvel em detergente neutro, nitrogênio insolúvel em detergente ácido e proteína insolúvel em detergente ácido, não houve efeito interativo de variedade com fração da parte aérea $(\mathrm{P}>0,05)$, assim como não houve efeito de variedade (Tabela 5). 
Rev. Bras. Saúde Prod. Anim., Salvador, v.13, n.3, p.604-618 jul./set., 2012 http://www.rbspa.ufba.br ISSN 15199940

Tabela 5. Percentuais das frações nitrogenadas A, B3 e C, em relação ao nitrogênio total, e NIDIN, PIDIN, NIDA e PIDA, em percentagem da matéria seca, do feno de quatro variedades de mandioca

\begin{tabular}{lrcrrrrr}
\hline Variedade & Fração A & Fração B3 & Fração C & NIDIN & PIDIN & NIDA & PIDA \\
\hline Amarelinha & $10,46^{\mathrm{a}}$ & $23,22^{\mathrm{a}}$ & $1,35^{\mathrm{a}}$ & $2,13^{\mathrm{a}}$ & $13,33^{\mathrm{a}}$ & $1,48^{\mathrm{a}}$ & $9,29 \mathrm{a}$ \\
Olho Roxo & $8,65^{\mathrm{a}}$ & $27,94^{\mathrm{a}}$ & $1,16^{\mathrm{a}}$ & $2,00^{\mathrm{a}}$ & $12,49^{\mathrm{a}}$ & $1,25^{\mathrm{a}}$ & $7,85^{\mathrm{a}}$ \\
Periquita & $6,63^{\mathrm{a}}$ & $25,82^{\mathrm{a}}$ & $1,38^{\mathrm{a}}$ & $2,23^{\mathrm{a}}$ & $13,99^{\mathrm{a}}$ & $1,51^{\mathrm{a}}$ & $9,48^{\mathrm{a}}$ \\
Sabará & $7,40^{\mathrm{a}}$ & $24,97^{\mathrm{a}}$ & $1,26^{\mathrm{a}}$ & $2,12^{\mathrm{a}}$ & $13,29^{\mathrm{a}}$ & $1,37^{\mathrm{a}}$ & $8,59^{\mathrm{a}}$ \\
\hline Média Geral & 8,28 & 25,49 & 1,29 & 2,12 & 13,28 & 1,40 & 8,80 \\
\hline CV $(\%)$ & 45,55 & 37,07 & 22,10 & 14,99 & 15,05 & 23,00 & 23,08 \\
\hline
\end{tabular}

$\mathrm{A}$ = nitrogênio não protéico; $\mathrm{B} 3$ = proteínas de lenta degradação ruminal; $\mathrm{C}=$ fração indegradável; NIDIN = nitrogênio insolúvel em detergente neutro; PIDIN = proteína insolúvel em detergente neutro; NIDA = nitrogênio insolúvel em detergente ácido; PIDA = proteína insolúvel em detergente ácido.

Médias seguidas de mesma letra, na coluna, não diferem estatisticamente entre si pelo teste Scott \& Knott ao nível de 5\% de significância.

Nunes Irmão et al. (2008), ao avaliarem o feno da variedade de mandioca Coqueiro encontraram em plantas colhidas aos $8 \mathrm{e}$ 14 meses de plantio valores médios de 1,$73 ; 10,81 ; 0,86 ; 5,37 \%$ e 1,$53 ; 9,56$; 0,$77 ; 4,81 \%$ para NIDIN, PIDIN, NIDA, PIDA, respectivamente. No mesmo corpus, aos 12 e 14 meses de idade, foram observados teores de 40,78; 3,63 e $26,88 \%$ e 44,$44 ; 2,16$ e $15,43 \%$ para as frações A, B3 e C. Pode-se verificar que na mesma variedade alguns meses a mais para a colheita do material foram suficiente para que houvesse uma mudança considerável nas frações proteicas. Fato que também explica a diferença encontrada, quando se compara com as variedades deste estudo. as quais foram colhidas aos 8 meses de plantio. Neste experimento observou-se que as variedades apresentaram baixos níveis da fração proteica $\mathrm{C}$, o que as tornam boas fontes de proteína, visto que, a fração $\mathrm{C}$ não é aproveitada pela microbiota ruminal, nem pelo próprio animal.

No que respeita ao feno das diferentes frações da parte aérea, verificou-se que os teores das frações nitrogenadas A e B3 não apresentaram efeito significativo $(\mathrm{P}>0,05)$. No entanto, ao se comparar os teores da fração C, NIDN, PIDN, NIDA e PIDA, observou-se que o feno da planta inteira teve menores teores $(\mathrm{P}<0,05)$ (Tabela 6). O menor teor de lignina da fração planta inteira no material original, provavelmente, influenciou nestes resultados.

Malafaia et al. (1998), ao trabalharem com o feno da parte aérea total de mandioca encontraram valores para a fração "A" + "B1" de 37\%; para a fração "B3" de $26,94 \%$ e para a fração "C" de 25,48\%. Com relação à fração nitrogenada do feno da parte aérea da mandioca, Veloso et al. (2006) encontraram valores de $3,60 \%$ de NIDN, para PIDN 22,5\%, para 0 NIDA $2,46 \%$ e para PIDA $15,37 \%$, respectivamente. Já Pinho et al. (2004), em estudo equivalente, encontraram para NIDN, 2,88\%, para PIDN, $18 \%$, para NIDA, $1,53 \%$ e para PIDA, 9,56\%, respectivamente. Mais uma vez, a grande variação na composição nutricional da parte aérea é confirmada pela divergência nos resultados desta pesquisa em relação às médias encontradas pelos autores acima. Esses dados são fruto, provavelmente, de diferenças varietais, fração da parte 
Rev. Bras. Saúde Prod. Anim., Salvador, v.13, n.3, p.604-618 jul./set., 2012 http://www.rbspa.ufba.br ISSN 15199940

aérea e condições edafoclimáticas, visto que, neste experimento esperava-se que a fração planta inteira apresentasse maiores níveis da fração $\mathrm{C}$, NIDN,
PIDN, NIDA e PIDA, em função da alta proporção de caule presente nesta fração, fato este não observado.

Tabela 6. Percentuais das frações nitrogenadas A, B3 e C, em relação ao nitrogênio total, e NIDIN, PIDIN, NIDA e PIDA, em percentagem da matéria seca, do feno de diferentes frações da parte aérea de mandioca

\begin{tabular}{lrrrrrrr}
\hline $\begin{array}{l}\text { Fração da parte } \\
\text { aérea }\end{array}$ & Fração A & Fração B3 & Fração C & NIDN & PIDN & NIDA & PIDA \\
\hline Planta inteira & $9,47^{\mathrm{a}}$ & $25,57^{\mathrm{a}}$ & $1,06^{\mathrm{a}}$ & $1,75^{\mathrm{a}}$ & $10,98^{\mathrm{a}}$ & $1,17^{\mathrm{a}}$ & $7,33^{\mathrm{a}}$ \\
Terço superior & $7,41^{\mathrm{a}}$ & $29,49^{\mathrm{a}}$ & $1,34^{\mathrm{b}}$ & $2,42^{\mathrm{b}}$ & $15,15^{\mathrm{b}}$ & $1,46^{\mathrm{b}}$ & $9,12^{\mathrm{b}}$ \\
Sobras de plantio & $7,98^{\mathrm{a}}$ & $21,41^{\mathrm{a}}$ & $1,46^{\mathrm{b}}$ & $2,19^{\mathrm{b}}$ & $13,70^{\mathrm{b}}$ & $1,59^{\mathrm{b}}$ & $9,95^{\mathrm{b}}$ \\
\hline Média Geral & 8,28 & 25,49 & 1,29 & 2,12 & 13,28 & 1,40 & 8,80 \\
\hline CV $(\%)$ & 75,55 & 37,07 & 22,10 & 14,99 & 15,05 & 23,00 & 23,08 \\
\hline
\end{tabular}

$\mathrm{A}=$ nitrogênio não protéico; $\mathrm{B} 3$ = proteínas de lenta degradação ruminal; $\mathrm{C}=$ fração indegradável; NIDIN = nitrogênio insolúvel em detergente Neutro; PIDIN = proteína insolúvel em detergente neutro; NIDA = nitrogênio insolúvel em detergente ácido; PIDA = proteína insolúvel em detergente ácido; Médias seguidas de mesma letra, na coluna, não diferem estatisticamente entre si pelo teste Scott \& Knott ao nível de 5\% de significância

Para a fração B1, ao se comparar variedade dentro de cada fração, notou-se diferença significativa $(\mathrm{P}<0,05)$ somente para a fração planta inteira. Ressalte-se que nesta, a variedade Olho Roxo apresentou maior percentual (Tabela 7). Já, ao se comparar fração dentro de cada variedade houve diferença $(\mathrm{P}<0,05)$ na variedade Olho Roxo, na qual a fração planta inteira apresentou maior percentual. Na variedade Periquita, a fração sobras de plantio apresentou maior teor e, na variedade Sabará, as frações planta inteira e sobras de plantio também apresentaram maiores percentuais. Esses resultados podem estar relacionados à alta proporção de caule e folhas presentes nessas duas frações, planta inteira $\mathrm{e}$ sobras de plantio, em relação a fração terço superior que, em grande parte da sua composição, era de folhas, como pode ser visualizado na tabela 2 com os dados da relação folha/haste. Para a fração B2, ao se comparar variedade dentro de cada fração e também fração dentro de cada variedade, verificou-se diferença significativa $(\mathrm{P}<0,05)$ somente para a fração planta inteira da variedade Olho Roxo, que apresentou menor média em relação as demais. Provavelmente, o menor diâmetro de rama encontrado na variedade Olho Roxo contribuiu para esses baixos níveis da fração B2. As proporções médias das frações nitrogenadas A + B1 $(32,88 \%)$ e B2 + B3 $(65,8 \%)$, nos fenos produzidos com a parte aérea da mandioca, sugerem para um bom aproveitamento do nitrogênio total, tanto pela microbiota ruminal, como pelo próprio animal.

Nunes Irmão et al. (2008), em estudo do feno do terço superior da parte aérea da mandioca da variedade Coqueiro, em plantas colhidas aos $8 ; 10 ; 12 ; 14 ; 16$ e 18 meses, observaram teores médios de $6,56 \% ; 5,68 \% ; 2,58 \% ; 11,71 \% ; 20,96 \%$ e $10,20 \%$ para a fração B1 e $30,82 \%$; $35,26 \%$; $26,40 \%$; $24,95 \%$; 
Rev. Bras. Saúde Prod. Anim., Salvador, v.13, n.3, p.604-618 jul./set., 2012 http://www.rbspa.ufba.br ISSN 15199940

$38,92 \% ; \quad 38,08 \%$ para a fração B2, respectivamente. Os resultados das frações B2 deste experimento mostram o bom desempenho das variedades em relação ao seu valor nutricional, visto que, quanto ao valor proteico a fração B2 é aproveitada de maneira eficiente pelos microorganismos presentes no ambiente ruminal e pelo animal.

Tabela 7. Percentagem da fração B1 (proteínas de rápida degradação) e fração B2 (proteínas de degradação intermediária), em relação ao nitrogênio total (\%NT) do feno de diferentes frações da parte aérea de variedades de mandioca

\begin{tabular}{|c|c|c|c|}
\hline \multirow{3}{*}{ Variedade } & \multicolumn{3}{|c|}{ Fração proteica B1 } \\
\hline & \multicolumn{3}{|c|}{ Fração da parte aérea } \\
\hline & Planta inteira & Terço superior & Sobras de plantio \\
\hline Amarelinha & $19,96^{\mathrm{Ab}}$ & $21,39^{\mathrm{Aa}}$ & $23,26^{\text {Aa }}$ \\
\hline Olho Roxo & $40,07^{\mathrm{Aa}}$ & $17,24^{\mathrm{Ca}}$ & $29,11^{\mathrm{Ba}}$ \\
\hline Periquita & $22,96^{\mathrm{Bb}}$ & $14,74^{\mathrm{Ba}}$ & $33,79^{\mathrm{Aa}}$ \\
\hline Sabará & $25,28^{\mathrm{Ab}}$ & $16,64^{\mathrm{Ba}}$ & $30,80^{\mathrm{Aa}}$ \\
\hline Média Geral & \multicolumn{3}{|c|}{24,60} \\
\hline $\mathrm{CV}(\%)$ & \multicolumn{3}{|c|}{23,25} \\
\hline \multicolumn{4}{|c|}{ Fração proteica B2 } \\
\hline \multirow{2}{*}{ Variedade } & \multicolumn{3}{|c|}{ Fração da parte aérea } \\
\hline & Planta inteira & Terço superior & Sobras de plantio \\
\hline Amarelinha & $50,05^{\mathrm{Aa}}$ & $40,29^{\mathrm{Aa}}$ & $39,89^{\mathrm{Aa}}$ \\
\hline Olho Roxo & $19,48^{\mathrm{Bb}}$ & $41,59^{\mathrm{Aa}}$ & $39,20^{\mathrm{Aa}}$ \\
\hline Periquita & $36,75^{\mathrm{Aa}}$ & $49,57^{\mathrm{Aa}}$ & $40,62^{\mathrm{Aa}}$ \\
\hline Sabará & $40,95^{\mathrm{Aa}}$ & $45,49^{\mathrm{Aa}}$ & $39,88^{\mathrm{Aa}}$ \\
\hline Média Geral & & 40,31 & \\
\hline $\mathrm{CV}(\%)$ & & 21,45 & \\
\hline
\end{tabular}

Médias seguidas de mesma letra, maiúsculas na linha e minúscula na coluna, não diferem estatisticamente entre si pelo teste Scott \& Knott ao nível de 5\% de significância.

Ao avaliar as variedades, os teores de carboidratos totais e fração B2 dos carboidratos observou-se que tais parâmetros não diferiram $(\mathrm{P}>0,05)$. No entanto, as variedades Amarelinha e Olho Roxo apresentaram menores teores de carboidratos fibrosos e maiores teores de carboidratos não fibrosos, ou fração $\mathrm{A}+\mathrm{B} 1$, em função, provavelmente, do menor diâmetro de rama encontrada nessas variedades (Tabela 8). Esse fato também foi observado quando se avaliou a fração $C$, na qual a variedade Amarelinha apresentou um menor percentual.
Os fenos das variedades de mandioca apresentaram em média $76 \%$ das frações $\mathrm{A}+\mathrm{B} 1+\mathrm{B} 2$ e $24 \%$ da fração C, o que mostra um bom potencial de utilização na alimentação de ruminantes. Quando comparados aos dados de Nunes Irmão et al. (2008), as frações A+B1 (carboidratos não fibrosos) se encontram dentro do intervalo de 15,04 a $29,84 \%$, no entanto, os valores das frações B2 (4,4 a 11,73\%) são superiores enquanto que os da fração C (29,99 a 39,03\%) são inferiores. Cabe lembrar que a fração B2 e C correspondem aos carboidratos fibrosos. 
Rev. Bras. Saúde Prod. Anim., Salvador, v.13, n.3, p.604-618 jul./set., 2012 http://www.rbspa.ufba.br ISSN 15199940

Tabela 8. Teores de carboidratos totais ( $\mathrm{CHO}$ total), carboidratos fibrosos (CHO fibroso) e carboidratos não fibrosos ( $\mathrm{CHO}$ não fibroso) em percentagem da matéria seca e percentagem das frações $\mathrm{A}+\mathrm{B} 1$, B2 e $\mathrm{C}$ em relação aos carboidratos totais do feno de quatro variedades de mandioca

\begin{tabular}{lccccc}
\hline Variedade & $\begin{array}{c}\text { CHO } \\
\text { total }\end{array}$ & $\begin{array}{c}\text { CHO } \\
\text { fibroso }\end{array}$ & $\begin{array}{c}\text { CHO (não fibroso)/ } \\
\text { Fração A + B1 }\end{array}$ & Fração B2 & Fração C \\
\hline Amarelinha & $70,41^{\mathrm{a}}$ & $48,74^{\mathrm{b}}$ & $21,67^{\mathrm{a}}$ & $60,44^{\mathrm{a}}$ & $18,99^{\mathrm{b}}$ \\
Olho roxo & $70,12^{\mathrm{a}}$ & $49,67^{\mathrm{b}}$ & $20,45^{\mathrm{a}}$ & $55,22^{\mathrm{a}}$ & $24,31^{\mathrm{a}}$ \\
Periquita & $68,34^{\mathrm{a}}$ & $51,93^{\mathrm{a}}$ & $16,40^{\mathrm{b}}$ & $57,78^{\mathrm{a}}$ & $25,80^{\mathrm{a}}$ \\
Sabará & $69,88^{\mathrm{a}}$ & $54,08^{\mathrm{a}}$ & $15,79^{\mathrm{b}}$ & $57,04^{\mathrm{a}}$ & $27,15^{\mathrm{a}}$ \\
\hline Média Geral & 69,69 & 51,10 & 18,58 & 57,62 & 24,06 \\
\hline CV $(\%)$ & 4,09 & 7,28 & 17,57 & 9,07 & 16,05 \\
\hline
\end{tabular}

Médias seguidas de mesma letra, na coluna, não diferem estatisticamente entre si pelo teste Scott \& Knott ao nível de 5\% de significância. Fração A (açúcares solúveis), Fração B1 (amido, polissacarídeos não estruturais: pectinas, galactinas, frutosanas etc), Fração B2 (fibra disponível), Fração C (fibra indisponível).

Em relação às diferentes frações da parte aérea verificou-se que o feno da fração planta inteira apresentou maior teor de carboidratos totais $(\mathrm{P}<0,05)$, e o feno do terço superior apresentou menores teores de carboidratos fibrosos, em função da menor proporção de caule, e fração C de carboidratos, reflexo do menor teor de lignina no feno do terço superior (Tabela 9). Já em relação aos carboidratos não fibrosos (fração $\mathrm{A}+\mathrm{B} 1$ ) e fração $\mathrm{B} 2$, não houve diferença $(\mathrm{P}>0,05)$ entre os fenos das diferentes frações da parte aérea.

Tabela 9. Teores de carboidratos totais ( $\mathrm{CHO}$ total), carboidratos fibrosos (CHO fibroso) e carboidratos não fibrosos ( $\mathrm{CHO}$ não fibroso) em percentagem da matéria seca e percentagem das frações $A+B 1, B 2$ e $C$ em relação aos carboidratos totais do feno de diferentes frações da parte aérea de mandioca

\begin{tabular}{lccccc}
\hline $\begin{array}{l}\text { Fração da parte } \\
\text { aérea }\end{array}$ & $\begin{array}{c}\text { CHO } \\
\text { total }\end{array}$ & $\begin{array}{c}\text { CHO } \\
\text { fibroso }\end{array}$ & $\begin{array}{c}\text { CHO não fibroso/ } \\
\text { Fração A +B1 }\end{array}$ & Fração B2 & Fração C \\
\hline Planta inteira & $74,95^{\mathrm{a}}$ & $57,22^{\mathrm{a}}$ & $17,71^{\mathrm{a}}$ & $55,27^{\mathrm{a}}$ & $27,00^{\mathrm{a}}$ \\
Terço superior & $65,05^{\mathrm{c}}$ & $44,96^{\mathrm{c}}$ & $20,08^{\mathrm{a}}$ & $60,08^{\mathrm{a}}$ & $20,65^{\mathrm{b}}$ \\
Sobras de plantio & $69,06^{\mathrm{b}}$ & $51,12^{\mathrm{b}}$ & $17,94^{\mathrm{a}}$ & $57,51^{\mathrm{a}}$ & $24,54^{\mathrm{a}}$ \\
\hline Média Geral & 69,69 & 51,10 & 18,58 & 57,62 & 24,06 \\
\hline CV $(\%)$ & 4,09 & 7,28 & 17,57 & 9,07 & 16,05 \\
\hline
\end{tabular}

Médias seguidas de mesma letra, na coluna, não diferem estatisticamente entre si pelo teste Scott \& Knott ao nível de 5\% de significância.

Fração A = açúcares solúveis; Fração B1 = amido, polissacarídeos não estruturais: pectinas, galactinas, frutosanas etc.; Fração B2 = fibra disponível; Fração C = fibra indisponível. 
Embora no feno do terço superior os níveis de carboidratos totais sejam inferiores, a disponibilidade destes para o suprimento de energia para o rúmen e, consequentemente, para o animal é maior em função do menor percentual da fração C.

A fração planta inteira da variedade Periquita apresenta maior potencial produtivo de forragem na forma de feno. A fração terço superior da parte aérea da mandioca apresenta melhores resultados quanto à relação folha/haste dos fenos da parte aérea das variedades testadas. Os fenos produzidos da parte aérea das variedades Amarelinha e Olho Roxo apresentam melhor valor nutricional, assim como, o feno do terço superior. Todavia, o feno produzido a partir das sobras do plantio mostra potencial nutricional para utilização na alimentação de ruminantes.

\section{AGRADECIMENTOS}

À FAPEMIG, pelo apoio financeiro e ao $C N P q$ pelo auxílio com bolsa.

\section{REFERÊNCIAS}

ARAÚJO, M.J.; MEDEIROS, A.N.; CARVALHO, F.F.R.; SILVA, D.S.; CHAGAS, E.C.O. Consumo e digestibilidade dos nutrientes em cabras Moxotó recebendo dietas com diferentes níveis de maniçoba. Revista Brasileira de Zootecnia, v.38, n.6, p.1088-1095, 2009.

AZEVEDO, E.B.; NÖRNBERG, J.L.; KESSLER, J.D.; BRÜNING, G.; DAVID, D.B.; FALKENBERG, J.R.; CHIELLE, Z.G. Silagem da parte aérea da mandioca. Ciência Rural, v.36, n.6, p.1902-1908, 2006.
CARVALHO, G.G.P.; PIRES, A.J.V.; VELOSO, C.M.; DETMANN, E.; SILVA, F.F.; SILVA, R.R.

Degradabilidade ruminal do feno de alguns alimentos volumosos para ruminantes. Arquivo Brasileiro de Medicina Veterinária e Zootecnia, v.58, n.4, p.575-580, 2006.

CARVALHO JÚNIOR, J.N.; PIRES, A.J.V.P.; SILVA, F.F.; VELOSO, C.M.; CRUZ, C.L.S.; CARVALHO, G.G.P. Desempenho de ovinos mantidos com dietas com capimelefante ensilado com diferentes aditivos. Revista Brasileira de Zootecnia, v.38, n.6, p.994-1000, 2009.

CRUZ, F.G.G.; PEREIRA FILHO, M.; CHAVES, F.A.L. Efeito da substituição do milho pela farinha da apara de mandioca em rações para poedeiras comerciais. Revista Brasileira de Zootecnia, v.35, n.6, p.2303-2308, 2006.

\section{FERREIRA, D.F. SISVAR - SISTEMA DE ANÁLISE ESTATÍSTICA PARA DADOS BALANCEADOS. Lavras: DCE/UFLA, 2000.}

FERREIRA, G.D.G.; OLIVEIRA, R.L.; CARDOSO, E.C.; MAGALHÃES, A.L.R.; BRITO, E.L. Valor nutritivo de co-produtos da mandioca. Revista Brasileira de Saúde e Produção Animal [Online], v.8, n.4, p.364-374, 2007.

FIGUEIREDO, M.P.; SOUZA, L.F.; FERREIRA, J.Q. Cinética da degradação ruminal da matéria seca da haste, da raiz, do feno da parte aérea e da silagem de raiz de mandioca (Manihot esculenta Crantz) tratada com uréia. Brazilian Journal of Veterinary Research and Animal Science, v.43, n.1 p.11-17, 2006. 
Rev. Bras. Saúde Prod. Anim., Salvador, v.13, n.3, p.604-618 jul./set., 2012 http://www.rbspa.ufba.br ISSN 15199940

FOX, D.G.; TEDESCHI, L.O.; TYLUTKY, T.P.; VAN AMBURG, M.E.; CHASE, L.E.; PELL, A.N.; OVERTON, T.R.; RASMUUSSEN, C.N.; DURBAL. V.M. The cornell net carbohydrate and protein system model for evaluating herd nutrition and nutrient excretion. Animal Feed Science and Technology, v.112, n.1-4, p.29-78, 2002.

GOMES, L.A.A.; SILVA, E.C.; FAQUIN, V. Recomendações de adubação para cultivos em ambiente protegido. In: RIBEIRO, A.C.; GUIMARÃES, P.T.G.; ALVAREZ, V. H. (Ed.). Recomendações para o uso de corretivos e fertilizantes em Minas Gerais: $\mathbf{5}^{\mathrm{a}}$ aproximação. Viçosa,MG: Universidade Federal de Viçosa, 1999.

\section{HALL, M.B. Neutral detergent-} soluble carbohydrates nutritional relevance and analysis. A laboratory manual. Gainsville: University of Florida, 2003. 42p. (Extension Bulletin, 339).

MALAFAIA, P.A.M.; VALADARES FILHO. S.C.; VIEIRA, R.A.M.; SILVA, J.F.C.; PEREIRA, J.C. Determinação das frações que constituem os carboidratos totais e da cinética ruminal da fibra em detergente neutro de alguns alimentos para ruminantes. Revista Brasileira de Zootecnia, v.27, n.4, p.790-796, 1998.

MIRANDA, L.F.; PEREIRA, E.S.; RODRIGUEZ, N.M.; GONTIJO NETO, N.M.; ARRUDA, A.M.V. Avaliação da composição protéica e aminoacídica de forrageiras tropicais. Revista Caatinga, v.21, n.1, p.36-42, 2008.
MODESTO, E.C.; SANTOS, G.T.;

VILELA, D.; SILVA, D.C.;

FAUSTINO, J.O.; JOBIM, C.C.; DETMANN, E.; ZAMBOM, M.A.; MARQUES, J.A. Caracterização químicobromatológica da silagem do terço superior da rama de mandioca. Acta Scientiarum Animal Science, v.26, n.1, p.137-146, 2004.

MOURA, G.M; COSTA, N.L. Efeito da freqüência e altura de poda na produtividade de raízes e parte aérea em mandioca. Pesquisa Agropecuária Brasileira, v.36, n.8, p.1053-1059, 2001.

NATIONAL RESEARCH COUNCIL NRC. Nutrient requirements of dairy cattle. 7.ed. Washington, D. C.:

National Academy of Sciences, 2001.

NUNES IRMÃO, J.; FIGUEIREDO, M.P.; PEREIRA, L.G.R.; FERREIRA, J.Q.; RECH, J.L.; OLIVEIRA, B.M. Composição química do feno da parte aérea da mandioca em diferentes idades de corte. Revista Brasileira de Saúde e Produção Animal [Online], v.9, n.1, p.158-169, 2008.

OLIVEIRA, J.B.; PIRES, A.J.V.; CARVALHO, G.G.P.; RIBEIRO, L.S.O.; CRUZ, J.F.; GARCIA, R.; CARVALHO JÚNIOR, J.N.;

CHAGAS, D.M.T. Capim-elefante ensilado com casca de café, farelo de cacau ou farelo de mandioca. Revista Brasileira de Zootecnia, v.38, n.1, p.34-39, 2009.

PINHO, E.Z.; COSTA, C.; ARRIGONI, M.B.; SILVEIRA, A.C.; PADOVANI, C.R.; PINHO, S.Z. Fermentation and nutritive value of silage and hay made from the aerial part of cassava (Manihot esculenta Crantz). Scientia Agricola, v.61, n.4, p.364 -370, 2004. 
Rev. Bras. Saúde Prod. Anim., Salvador, v.13, n.3, p.604-618 jul./set., 2012 http://www.rbspa.ufba.br ISSN 15199940

PIRES, A.J.V.; CARVALHO, G.G.P.; GARCIA, R.; CARVALHO JÚNIOR, J.N.; RIBEIRO, L.S.O.; CHAGAS,

D.M.T. Fracionamento de carboidratos e proteínas de silagens de capimelefante com casca de café, farelo de cacau ou farelo de mandioca. Revista Brasileira de Zootecnia, v.38, n.3, p. 422-427, 2009.

SCAPINELLO, C.; FALCO, J.E.; FURLAN, A.C.; FARIA, H.G. Valor nutritivo do feno da rama de mandioca (Manihot esculenta Crantz) para coelhos em crescimento. Revista Brasileira de Zootecnia, v.28, n.5, p.1063-1067, 1999.

SILVA, D.J.; QUEIROZ, A.C. Análise de alimentos: métodos químicos e biológicos. 3.ed. Viçosa: Universidade Federal de Viçosa, 2006. 235p.

SNIFFEN, C.J.; CONNOR, J.D.; VAN SOEST, P J.; FOX, D.G.; RUSSELL, J.B. A net carbohydrate and protein system for evaluating cattle diets: II. Carbohydrate and protein availability. Journal Animal Science, v.70, n.11, p.3562-3577, 1992.

SOUZA, F.G.; FIGUEIREDO, M.P.; OLIVEIRA, C.G.; FERREIRA, J.Q. Produtividade do feno, parte aérea e raízes de mandioca, sob diferentes espaçamentos e níveis de adubação nitrogenada em cultivos para a exploração do feno do terço superior da parte aérea. In: SEMINÁRIO DE INICIAÇÃO CIENTIFICA, 4., 2001. Anais... Vitoria da Conquista: Universidade Estadual do Sudoeste da Bahia, 2001. p.34-37.
VAN SOEST, P.J.; ROBERTSON, J.B.; LEWIS, B.A. Methods for dietary fiber, neutral detergent, and nonstarch polysaccharides in relation to animal nutrition. Journal Dairy Science, v.74, n.10, p.3583-3597, 1991.

VELOSO, C.M.; RODRIGUEZ, N.M.; CARVALHO, G.G.P.; PIRES, A.J.V.; MOURÃO, G.B.; GONÇALVES, L.C.; SAMPAIO, I.B.M. Degradabilidade ruminal da matéria seca e da proteína bruta de folhas e folíolos de forrageiras tropicais. Revista Brasileira de Zootecnia, v.35, n.2, p.613-617, 2006.

VONGSAMPHANH, P.; WANAPAT, M. Comparison of cassava hay yield and chemical composition of local and introduced varieties and effects of levels of cassava hay supplementation in native beef cattle fed on rice straw.

\section{Livestock Research for Rural}

Development, v.16, n.8, p.1-9, 2004.

Data de recebimento: 01/05/2011

Data de aprovação: 18/07/2012 